\title{
Breach of implied contract
}

In a legal dispute that has gone on for ten years, the Court of Appeals for the Federal Circuit recently affirmed a judgement of US \$54.1 million, plus post-judgement interest, for the University of Colorado and others against American Cyanamid Corp., a subsidiary of Wyeth. The judgement resulted from American Cyanamid's misappropriation of an idea developed by University of Colorado researchers Drs Robert Allen and Paul Seligman, who developed a formula for a prenatal vitamin called Materna that would permit increased iron absorption compared with vitamins available on the market. Allen and Seligman provided a confidential paper to American Cyanamid describing the improvement. Without informing the researchers, American Cyanamid applied for a patent that covered the improved vitamin and copied sections of the confidential paper into their application. After obtaining the patent, the corporation successfully enforced it against generic manufacturers. The University of Colorado, including Allen and Seligman, filed a claim for unjust enrichment against American Cyanamid. The Federal Circuit reasoned that the researchers did not seek 'patentlike protection' for their idea with their unjust enrichment claim.
Instead, it was really a claim for breach of an implied-in-law contract between the researchers and American Cyanamid relating to the confidentiality of the paper. The court also found that the researchers' claim did not conflict with the purposes of the patent system as explained in a prior Supreme Court decision (Aronson versus Quick Point Pencil, 1979), in which the court held that there is a strong federal policy favouring the full and free use of ideas in the public domain. In this case, the Federal Circuit held that a state law claim for unjust enrichment was not preempted by federal patent law. Recovery on the claim would allow the University of Colorado to benefit from the fruits of their invention, which ultimately fostered innovation, but would not withdraw ideas from the public domain.

After deductions for contractual/licensing commitments and attorney fees, the University of Colorado stands to receive $47.5 \%$ of the judgement, after legal costs, which will be distributed in accordance with the university policy on discovery and patents. Inventors Allen and Seligman, their research laboratories, their department and the university will each receive $25 \%$ of the proceeds distributed to the university.

\section{BMS wins lawsuit over CTLA4 patents}

Bad news for Repligen Corp., the

Massachusetts-based biotechnology company: a federal judge for the Eastern District of Michigan has ruled that the company has insufficient evidence to challenge a number of Bristol-Myers Squibb patents on the use of the immunological molecule CTLA4 as a drug for treating autoimmune diseases, including arthritis. Repligen, together with the University of Michigan, had challenged BMS patents for CTLA4, claiming that a university scientist, Craig Thompson, helped BMS scientists by making significant inventive contributions in discovering the activity of CTLA4-Ig, and arguing that the university and its partner Repligen deserved claim to the drug's patents. The judge ruled that there was insufficient evidence to prove that the university scientist was an inventor on the patent. However, there is some good news, as the US Patent and Trademark Office granted Repligen a patent for the use of CTLA4 in treating arthritis, multiple sclerosis and systemic lupus erythromatosus (SLE). The new patent is separate from those contested in the court case and is not yet published in the Federal Register, where patent allowances are made public. CTLA4 is a T-cell regulatory protein, which is a natural suppressor of the immune response. Animal experiments indicate that CTLA4-Ig has the potential to block unwanted immune responses without compromising the ability to fight off other infections. BMS is testing CTLA4 in humans for arthritis, multiple sclerosis and SLE, whereas Repligen is investigating the molecule for use in a rare-blood disorder called refractory immune thrombocytopaenic purpura.

\section{Canada to allow production of generic AIDS drugs}

In a surprising move, Paul Martin, the Canadian Prime Minister-elect, has endorsed plans for the federal government to excuse poor countries from patent rules, as permitted under a new international agreement. This allows Canadian generic-drug makers to supply cheap medicines to developing countries undergoing health crises. The World Trade Organization (WTO) deal creates a legal loophole that allows the most desperate countries to override patents on expensive drugs and order cheaper copies from generic manufacturers, with patent holders receiving a small payment. In fact in 2000, Canadian generic pharmaceutical manufacturer Apotex offered to provide
HIV/AIDS drugs to developing countries in sub-Saharan Africa at cost. Ultimately, this did not happen because Canadian patent law would not allow it. Canadian law protects patented medicines for 20 years, except for national distribution in emergencies. Eric Dagenais, director of patent policies for the Industry Ministry, said he would like to propose a bill in the next few weeks or months to the cabinet, which would allow Ottawa to force drug-makers in Canada to surrender their patents on AIDS drugs. Canada is the first G7/G8 nation to take such a step. Canada's research-based pharmaceutical companies will work with Ottawa to implement a WTO agreement to import cheaper drugs to developing nations, providing the countries can prove that they do not have the capacity to make the drugs themselves and that they are not going to sell the drugs on the black market.

This announcement follows on from progress made at the November 2001 international trade meetings in Doha, Qatar, when it was agreed that developing countries could import low-cost generic medicines in times of health crises. Many of the countries stricken with diseases such as HIV/AIDS do not have the domestic manufacturing capabilities to produce their own low-cost versions of the necessary drugs. 